\title{
Phytochemical Analysis and Biological Activity of Some Sudanese Medicinal Plants
}

\author{
Manal A. Ibrahim ${ }^{1 *}$, Nadia N. Abdel Gadir ${ }^{2}$ and Adam Kh. Musa ${ }^{3}$ \\ ${ }^{1,3}$ Department of Botany, Faculty of Science and Technology, Omdurman Islamic University Sudan \\ ${ }^{2}$ Department of Biochemistry, Nursing College, Omdurman Islamic University Sudan
}

\begin{abstract}
DOI: $\underline{10.36347 / \text { sajp.2020.v09i11.003 }}$
| Received: 19.10.2020 | Accepted: 04.11.2020 | Published: 11.11.2020

*Corresponding author: Manal, A. Ibrahim

Abstract

The plants under investigations (Boscia seneglansis, Boswellia papyrifera, Cadaba glandulosa, Aristolochia bracteulata and Nymphea lotus) were used in folkloric medicine in Sudan to cure some diseases. The results indicated a moderate presence of alkaloids on B. seneglansis and A. bracteulata and weak presence for N. lotus, C. glandulosa and B. papyriferae. Tannins were detected highly presence for B. seneglansis, N. lotus and moderate presence for other plants. Also flavonoids represented moderate presence for $\mathrm{N}$. lotus and weakly presence for other plants. Remarkable cytotoxicity revealed for B.seneglansis with high value equal to $1.975 \mu \mathrm{g} / \mathrm{ml}$. On the other hand B.paprifera, N.lotus, C.glandulosa and A. bracteulata represented cytotoxicity equal 14.96, 316.22, 635.1 and $>1000 \mu \mathrm{g} / \mathrm{ml} \mathrm{respectively.}$

Keywords: Phytochemical Analysis Biological Activity Medicinal Plants.

Copyright (C) 2020 The Author(s): This is an open-access article distributed under the terms of the Creative Commons Attribution 4.0 International License (CC BY-NC 4.0) which permits unrestricted use, distribution, and reproduction in any medium for non-commercial use provided the original author and source are credited.
\end{abstract}

\section{INTRODUCTION}

Plants are utilized as therapeutic agents since time out of mind in both organized and unorganized forms [1]. The healing properties of the many herbal medicines are recognized in many ancient cultures. The term of medicinal plants includes various sorts of plants utilized in herbalism and a few of those plants have a medicinal activity. Herbs are utilized in many domains, including medicine, nutrition, flavorings, beverages, dyeing, repellents, fragrances and cosmetics [2]. And Traditional herbal medicine as a serious African sociocultural heritage, obviously alive for several many years, was once believed to be primitive and wrongly challenged with animosity, especially by foreign religions. However, today traditional medicine has been brought into focus for meeting the goals of a wider coverage of primary health healthcare delivery, not only in Africa but also to various extents in all countries of the world [3]. In Sudan, people have been tapping their herbal remedies from education for time immemorial. For this purpose, they use a vast variety of plants ranging from the rain forest vegetation in the south, to the desert vegetation of the north, and from the semiMediterranean climatic zone of the red sea, to the rich savanna of the west [4]. Sudan has been home to indigenous civilization, like Meroe, and road for others, namely pharaonic, Christian and Islamic civilizations. The country has been heavily influenced by fusion of different cultures. The immigrant Arab culture and therefore the neighboring cultures (mainly Egyptian and West African cultures) have strongly influenced Sudanese culture. However, there's a good range of practices, which fall into the umbrella of traditional medicine [5], this encourage their use for the remedy of variety of diseases without supervision. Increased popularity and scarcity of scientific studies on the safety of these plants and their phytoconstituents have raised questions about their toxicity and adverse effects [6]. B.papyrifera plant (family Burseraceae, Fig 1) common name is Tarag trag - Rut-Rut, Gafal was distributed in Sudan in Blue Nile State (Jebel Elgarrie area, Ingasana and the border with Ethiopia), Southern Kordofan State in the Nuba Mountains. And Western Darfur, from Jebel Marra towards the west through Capitol Hill catenas of Zalingi to the south of Elgeneina until the border with the Republic of Chad [7]. It was claimed to have many medicinal applications, it produce a gum resin that is known as olibagum (frankincense). This natural resin has long been utilized in Ayurvedic and traditional Chinese medicine to treat a spread of health aspects [8] like inflammatory and arthritic diseases [9]. Several compounds isolated from these resins have growth inhibitory activity against cancer cells [10]. Moreover, boswellic acids can activate additional pathways in cancer cells. For example, boswellic acids can inhibit nuclear factor- $\kappa \mathrm{B}$ and STATs activities in tumor cells [11]. Boswellia species volatile oils are the 
most commonly used oils in aromatherapy. Chemical profile of those oils were analyzed and studied for his or her anti-tumor properties [12]. Nymphaea Lotus plant has a common name Soutab, Umm Ban geiga (Fig 2). It is aquatic pubescent herbs with submerged prostrate rhizomes, widespread throughout central and southern Sudan [13]. It is utilized in traditional medicine system as an aphrodisiac, anodyne, astringent, cardiotonic, sedative, demulcent, analgesic and as anti-inflammatory agent [14]. The leaves of lotus are traditionally used for the treatment of haematemesis, haematuria, metrorrhagia, hyperlipidaemia, fever and inflammatory skin conditions [15]. Many biological activities, including anticancer and antiviral has been attributed to Gallic and ellagic acid which are widely present in N. lotus [16]. In addition, the plant Aristolochia bracteolota which common name is Um galagel. (Family Aristolochiaceae Fig 3). It is a shrub or small tree [17]. It covers an expansive region in Sudan with a wide distribution in lowland plains and water catchment areas [18]. It is traditionally used as a remedy for scorpion and snake bites, pain, tumor, malaria and fever [18]. In African ethnomedicine, it is widely used as anti-inflammatory and anticancer [19]. The plant is known as "worm killer" due to supposed anthelmintic activity and trypanocidal effect. Furthermore, the A. bracteolata possesses potent anti-allergic, antibacterial and antifungal activities [20].

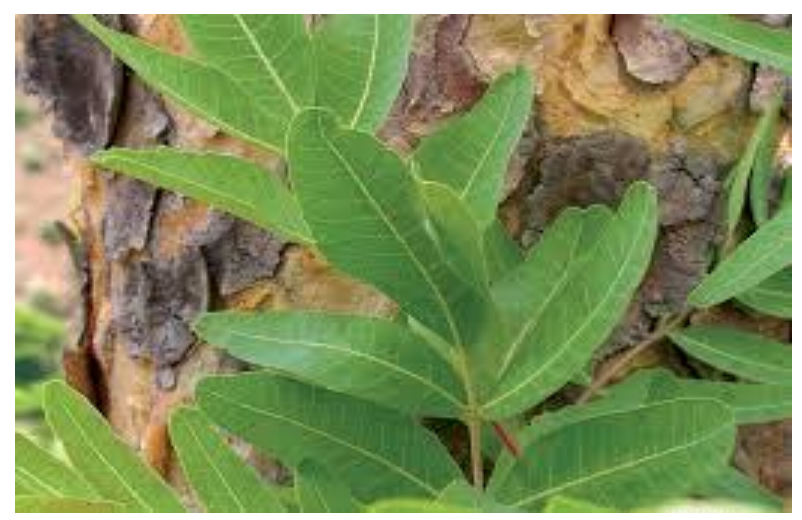

Fig-1: Boswellia papyrifera

Nymphaea Lotusplant has a common nameSoutab, Umm Ban geiga (Fig 2). It is aquatic pubescent herbs with submerged prostrate rhizomes, widespread throughout central and southern Sudan [4]. It is used in traditional medicine system as an aphrodisiac, anodyne, astringent, cardiotonic, sedative, demulcent, analgesic and as anti-inflammatory agent [14]. The leaves of lotus are traditionally used for the treatment of haematemesis, haematuria, metrorrhagia, hyperlipidaemia, fever and inflammatory skin conditions. Many biological activities, including anticancer and antiviral has been attributed to Gallic and ellagic acid which are widely present in N. lotus [16].

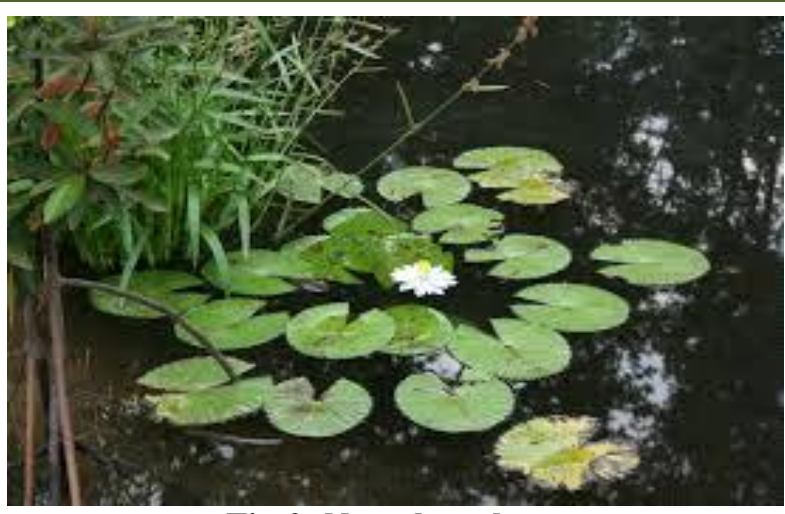

Fig-2: Nymphaea lotus

In addition, the plantAristolochia bracteolotawhich common name is Um galagel. (Family Aristolochiaceae Fig 3). It is a shrub or small tree [17].

It covers an expansive region in Sudan with a wide distribution in lowland plains and water catchment areas [18]. It is traditionally used as a remedy for scorpion and snake bites, pain, tumor, malaria and fever [18]. In African ethnomedicine, it is widely used as anti-inflammatory and anticancer [19]. The plant is known as "worm killer" due to supposed anthelmintic activity and trypanocidal effect. Furthermore, the A. bracteolata possesses potent anti-allergic, antibacterial and antifungal activities [20].

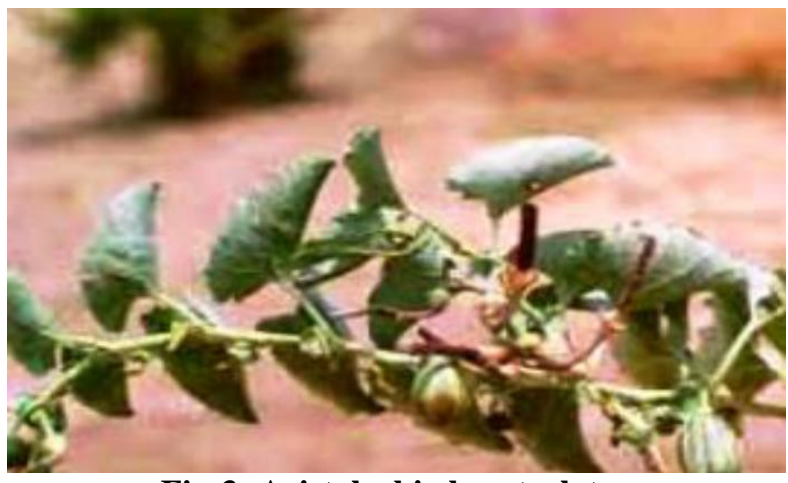

Fig-3: Aristolochia bracteolatea

Boscia senegalensis (Fig 4) which features a common name Elcrasan - Elmekheat belong to family Capparacea .It is a shrubs or small trees, The plant occurs across area that in recent decades has faced more hunger than the other within the world - the vast swath of Sahel and Sahara savannas stretching from Mauritania, Senegal, and Mali all the thanks to southeastern Egypt, Sudan, Ethiopia, Somalia, Kenya [21] and western Sudan [22]. It's usually eaten as a food with oil and salt. Alternatively, seeds are ground to flour which is consumed within the sort of kisra, flat thin bread popular in Sudan or Asida, an area sort of porridge. The taste of the ultimate product is often improved by blending with millet or sorghum flour [21]. 
The leaves are wont to protect stored food against parasites [23]. Consistent with the African folk medicine, an infusion of leaves is employed to get rid of intestinal parasites from camels. Leaves mixed with millet flour taken each morning on an empty stomach for anthelminthic; dried leaves or dried bark are taken for schist osmosis. Infusion of the leaves is employed as eyewash, pruritus of the attention thanks to syphilis and to relief intestinal pain [24]. The seeds of B. senegalensis are a valuable source of glucocapparin. This component which presents a stimulating antihyperglycemic effect might be associated with the normal use of the seeds in Chad against type 2 diabetes. However, the cytotoxicity effect acknowledged suggests that further investigations extended to would be needed to form the glucocapparin a possible antidiabetic drug [25]. One active principle in Boscia has been identified as a glucocapparin, a sulfonated glucose which exhibited not only hypoglycemic effect, but also cytotoxicity [26].

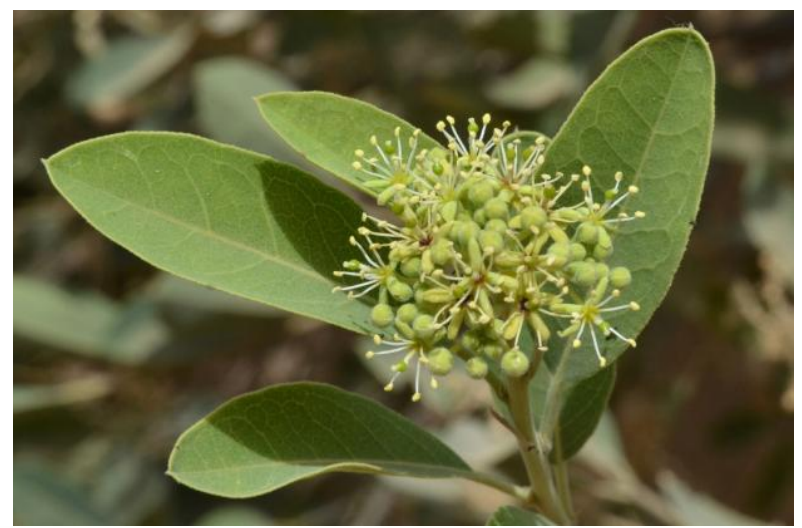

Fig-4: Bosciaseneglansis

Also Cadaba glandulosa may be a common name Elsrah. (Family Capparaceae Fig 5).It is a Shrub $0.3-1.5 \mathrm{~m}$ tall. The leaves are used for the treatment of hemorrhoids and tract infections [27]. Leaves, seeds and roots of the plant are widely used as an anthelmintic, antiscorbutic, antiseptic, cardiac stimulant, carminative, febrifuge sudorific, anticonvulsant, antidi- arrhoeal, and also are wont to treat skin diseases [28]. Several studies had shown that Artemia salina lethality may be a general bioassay which is a superb method for preliminary investigations of toxicity so as to screen of biologically active compounds [29]. The Artemia salina assay has been established as a secure, practical and economic method for the determination of the bioactivity of synthetic compounds [9]. However is studied so as to reveal new anticancer compounds [30]. Therefor this study aimed to guage the cytotoxicity of plant extracts as a replacement potential source of natural anti - tumor agent.

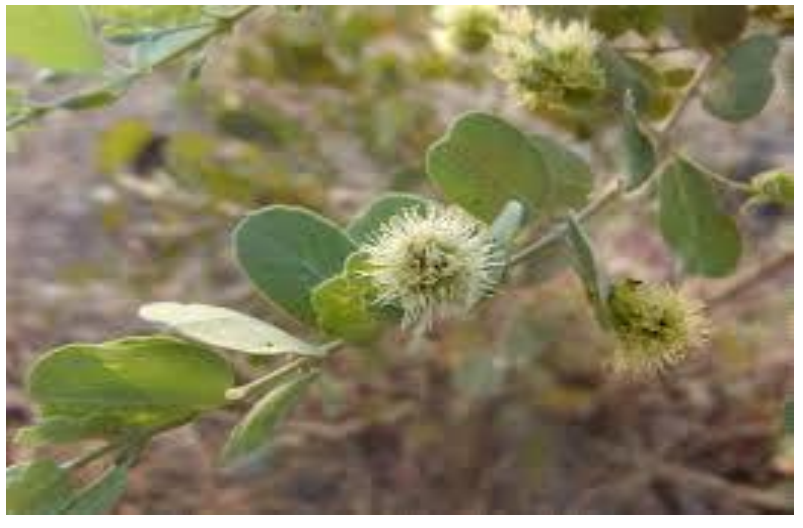

Fig-5: Cadabaglandulosa

\section{Plant materials}

The Plants under investigations (Cadaba glandulosa, Boswellia papyrifera, Aristolochia bracteolata, Boscia senegalensis), Leaves and lotus whole plant were Collected in April 2017 from Gabrat ALSHEAKH and Kadogly in South Kordofan and from Khartoum region. The plants were taxonomically identified by Mr. Yahya, Medicinal and Aromatic Plants Institute, National Center for Research, and Dr. Manal Abdalla, Department of Botany, Faculty of Science and Technology, Omdurman Islamic University.

\section{Preparation of Extract}

Plant parts (leaves and Nymphaealotus whole plant) were dried at room temperature in order to avoid any changes that may alter their chemical composition. Then, they were ground to a coarse powder before they were handled according to Harborne [30], The methanol solvent was used to extract secondary metabolite from leaves of plants and whole plant for N.lotus used in this study. $100 \mathrm{gm}$ of plant materials were soaked overnight with $350 \mathrm{ml} 98 \%$ methanol in $500 \mathrm{ml}$ conical flask. Then the extracts were filtered, evaporated to dryness under reduced pressure in a rotatory evaporator and weighted.

\section{Qualitative phytochemical Analysis}

Phytochemical screening for the identification of major groups of chemical constituents using standard procedures [30]. The phytochemical compounds which tested were tannins, saponins, flavonoids, terpenoids, Steroids, Alkaloids and phenolic compound.

\section{Chromatographic Separation}

TLC plates were prepared by using colloid F254 type G 60 as a stationary phase consistent with Harborne [30]. Variety of developing systems were prepared and lots of trials were administered so as to achieve the foremost suitable solvent systems that give good separation. 


\section{Brine Shrimp Lethality Test}

Brine shrimp lethality bio-assay was administered to research the cytotoxicity of plants extract. Brine shrimp (leach) eggs $(50 \mathrm{mg})$ were added to a hatching chamber containing sea water $(45 \mathrm{ml})$. The hatching chamber was kept under an inflorescent bulb for $48 \mathrm{~h}$ for the eggs to hatch into shrimp larvae. Test extract and fractions $(20 \mathrm{mg})$ were separately dissolved in $2 \mathrm{ml}$ of methanol, and then 5, 50 and $500 \mu \mathrm{l}$ of every solution were transferred into vials like 10, $1001000 \mu \mathrm{g}$ / ml, respectively. Each dosage was tested in triplicates. The vials 9 for every test) and one control containing $500 \mu \mathrm{l}$ of the solvent were allowed to evaporate to dryness in $48 \mathrm{~h}$ at temperature. Ten larvae of A. Salina leach (taken $48-72 \mathrm{~h}$ after the initiation of hatching) were added to every vial and therefore the final volume of the answer in each vial was adjusted to $5 \mathrm{ml}$ with sea water, immediately after adding the shrimps. One drop of dimethyl sulphoxide (D M SO) was added to the test and control vials before the addition of the shrimps to reinforce the solubility of the plant extract [32]. LC50 values were determined at $95 \%$ confidence intervals by analyzing the info on a computer loaded with a Finney program [33]. The LC50 values of the brine shrimps obtained for the studied plant extracts were recorded. Etoposide, the reference medicine, was used as a positive control with LC50 (7.46.).

\section{STATISTICAL ANALYSIS}

LC50 values were determined at $95 \%$ confidence intervals by analyzing the info on a computer loaded with a Finney Program [33].

\section{RESULTS AND DISCUSSION \\ Phytochemical Studies}

The methanol solvent which resulted in a better extractability was supported by the report of Harborne [31], who had stated that more polar plant metabolites were isolated from plant materials when alcohol or water were used for extraction. However, this does not exclude the other possibility that different extractable quantities may also depend on the type of plant part used, or in other ways the variations in extractability may be due to the nature of the solvent and the plant parts used. Methanol extracts of leaves and whole plant parts have sticky and solid consistencies, and green, dark green and dark brown colors. The solvent gave, generally, higher exorability with C.glandulosa than other plants (Table 1). The presence or absence of some secondary plants products were tested by procedures described by Harbone [31]. The results indicated a moderate presence of alkaloids on B. seneglansis and A. bracteulata and weak presence for N. lotus, C. glandulosa and B. papyriferae (Table 2). Alkaloids and saponins were detected particularly in the methanolic extract of B. papyrifera [34]. Tannins were detected highly presence for B. seneglansis, N. lotus and moderate presence for other plants. Capparaceae family, showed moderate to abundant presence of alkaloids. No scientific reports are there on the chemical composition or biological activity of any species belonging to these genera, although some novel alkaloids have been isolated from fruits and aerial parts of some Capparaceae [35]. Also flavonoids represented moderate presence for $\mathrm{N}$. lotus and weakly presence for other plants. It is reported that the lotus leaves are rich in flavonoids [36]. And alkaloids [37] and several flavonoids have been isolated [36]. Also triterpene showed weak presence for all plants used.

Table-1: Consistencies, color and extractabilities parts of all plants extracted with methanol

\begin{tabular}{|l|l|l|c|l|l|}
\hline No & Plants & Plant part & Consistency & Color & Extractability \% \\
\hline 1 & Aristolochia bracteulata & Leaves & Solid & Dark green & 8 \\
\hline 2 & Boswellia papyrifera & Leaves & Sticky & Dark brown & 6.3 \\
\hline 3 & Boscia seneglansis & Leaves & Solid & Dark green & 7.1 \\
\hline 4 & Cadaba glandulosa & Leaves & Solid & Green & 10.3 \\
\hline 5 & Nymphaea Lotus & Whole plant & Solid & Dark brown & 8.2 \\
\hline
\end{tabular}

The seeds and leaves of B. seneglansis were characterized by the presence of alkaloids, saponins and tannins [38].

In addition to, steroids were weakly presence in all plants, which was in disagreement with what was reported by Periyasamy and Mahalingam [15]. When they used methanol extracts of A. bracteolata, a moderate presence of steroids were showed. Also all plants revealed negative results for saponin, phenolic compound and triterpens. Saponine and triterpens were exhibited positive results when roots extract of A.bracteulata was used. Newman, et al. [39] And Jayanthi, et al. [40] reported that N. lotus have highly content of terpenoids, tannins and alkaloids. Phenolic compounds of Boscia seneglansis, especially flavonoids, Kampferol, quercetin and their derivatives proved to be effective against numerous cancer cell lines [14]. Mono terpenes in B. papyrifera have been reported to exert a wide variety of biological effects including antitumor activities [42]. 


\begin{tabular}{|c|c|c|c|c|c|c|}
\hline Compound & $\begin{array}{l}\text { Regents } \\
\text { Used }\end{array}$ & $\begin{array}{l}\text { Aristolochia } \\
\text { bracteulata }\end{array}$ & $\begin{array}{l}\text { Boswellia } \\
\text { paprifera }\end{array}$ & $\begin{array}{l}\text { Boscia } \\
\text { senegalensis }\end{array}$ & $\begin{array}{l}\text { Cadaba } \\
\text { glandulosa }\end{array}$ & $\begin{array}{l}\text { Nymphaea } \\
\text { lotus }\end{array}$ \\
\hline Alkaloid & Dragendorffs & ++ & + & ++ & + & + \\
\hline $\begin{array}{l}\text { Phenolic } \\
\text { compound }\end{array}$ & $\mathrm{KOH}$ & - & - & - & - & - \\
\hline Saponin & Frothing & - & - & - & - & - \\
\hline Tannine & Ferric Chloride & ++ & ++ & +++ & ++ & +++ \\
\hline Flavonoid & magnesium +HCL & + & + & ++ & + & ++ \\
\hline Steroid & Chloroform $+\mathrm{H}_{2} \mathrm{SO}_{4}$ Con & + & + & + & + & + \\
\hline Triterpene & Chloroform $+\mathrm{H}_{2} \mathrm{SO}_{4} \mathrm{Con}$ & + & + & + & + & + \\
\hline \multicolumn{7}{|c|}{$\begin{array}{c}+++=\text { High presence. } \\
++=\text { Moderate presence. } \\
+=\text { Weaknresence }\end{array}$} \\
\hline
\end{tabular}

\section{Separation of the Methanolic extracts Using TLC}

TLC separation of extracts was carried out in order to identify the different constituents of the extracts with respect to their Rf. values and colors of spots. The data obtained were compared with those from available literature, with similar experimental conditions.

The first group which consist of toluene: ethyl acetate: diethyl amine (70: 20: 10) gave five spots for Boscia seneglansis extract with dark blue color under UV $(365 \mathrm{~nm})$ while they gave orange color after the use of Dragendroff as spray reagent. On the other hand, Aristolochia bracteulata extract gave negative result with dark blue color under UV (365 nm) and were color less after the spray reagent (Table3).

Also Cadaba glandulosa extract gave six spots under UV $(365 \mathrm{~nm})$ changed to dark orange color with the suitable reagent. Positive results were obtained for Boswellia paprifera and Nymphaea lotus extracts using both UV and spray reagent. The Rf. Values for all previous spots reagent were between .0 .07 to .92 , these color indicated presence of alkaloid.

The second group which consisted of chloroform: glacial acetic acids: methanol: water (64: 32: 12: 8) was applied for all plant extracts (Table 4). The extracts of all plants did not give spots under UV and after spray with reagent.

The third solvent system which consisted of ethyl acetate: formic acid: glacial acid: water (100: 11: 11: 26) gave four spots for both Nymphaea lotus and Boswellia papyrifera extract with yellow colors with $\mathrm{KOH}$ as spray reagent. Also it gave two spots for Cadaba glandulosa, Aristolochia bracteulata and Boscia.seneglensis extracts with reagent and blue color under UV. The Rf. values for all previous spots reagent between .0 .06 to 0.95 . These colors indicated the presence of flavonoids (Table 5).

Table-3: TLC separation of plants extract for alkaloids representing florescemce, color and Rf values of the spots obtained by using a solvent system of toluene: ethyl acetate: diethyl amine (70: 20: 10) and sprayed with Dragendroff.

\begin{tabular}{|c|c|c|c|c|c|c|c|c|}
\hline Plants & & Color with reagent & \multicolumn{6}{|c|}{$\mathbf{R f}$} \\
\hline A.bracteulata & \multirow{5}{*}{ Blue and Red dark } & ellow/orange & - & - & - & - & - & - \\
\hline B.papyrifera & & & 0.38 & 0.43 & 0.48 & - & - & - \\
\hline B.senegalensis & & & 0.12 & 0.43 & 0.60 & 0.73 & 0.86 & - \\
\hline C.gladulosa & & & 0.18 & 0.28 & 0.50 & 0.60 & 0.79 & 0.85 \\
\hline N.lotus & & & 0.07 & 0.89 & 0.92 & $-s$ & - & - \\
\hline
\end{tabular}

Table-4: TLC separation of plant extracts for flavonoids representing, color and Rf values of the spots obtained by using a solvent system ethyl acetate: formic acid: glacial acid: water (100: 11: 11: 26) and sprayed with KOH in water (10\%)

\begin{tabular}{|c|c|c|c|c|c|c|c|c|}
\hline Plants & Color .UV 365 nm & Color with reagent & \multicolumn{6}{|c|}{ R. F } \\
\hline A.bracteulata & Blue dark & \multirow{5}{*}{ Yellow/brown } & 0.06 & 0.12 & - & - & - & - \\
\hline B.papyrifera & Blue & & 0.10 & 0.31 & 0.75 & 0.95 & - & - \\
\hline B.senegalensis & Blue dark & & 0.10 & 0.82 & - & - & - & - \\
\hline C.glandulosa & Blue & & 0.12 & 0.95 & - & - & - & - \\
\hline N.lotus & Red dark & & 0.06 & 0.68 & 0.81 & 0.88 & - & - \\
\hline
\end{tabular}

The fourth solvent system which consisted of ethyl acetate: methanol: water (100: 135: 10) (Table 5) gave two spots for both B. senegalensis and A. bracteulata extracts, on the other hand C.glandulosa and B.paprifera extracts represented three spots with blue green color. The last one was N.lotus exhibited four spots. All spots with blue and green color with Berlin blue as spray reagent and blue color under UV. This color showed Rf values between.08-.87 and indicated presence of tannins. 
The last one consists of toluene: ethyl acetate: ferric acid (50: 40: 10) (Table 7) was used for detection of phenol compounds (Table 6). The chromatographic separation gave positive results for B.seneglansis and B. papyrifera extracts with five spots, while
A.bracteulatarevealed negative result. Also N.lotusrevealed two spots. However, with the use of spray reagent, brown and pale brown colors were detected (Rf. Values between .10 - .63).

Table-5: TLC separation of plant extracts for tannins representing florescence, color and R.f values by using a solvent system ethyl acetate: methanol: water (100: 135: 10) and spray reagents: Berlin blue

\begin{tabular}{|l|l|c|l|l|l|l|l|}
\hline \multicolumn{1}{|c|}{ Plants } & Color .UV 365 nm & Color with reagent & \multicolumn{5}{|c|}{ Rf value } \\
\hline A.bracteulata & Blue dark & & 0.18 & 0.37 & - & - & - \\
\hline B.papyrifera & Blue & \multirow{4}{*}{ Blue/green } & 0.25 & 0.60 & 0.87 & - & - \\
\hline B.seneglansis & Blue dark & 0.12 & 0.31 & - & - & - \\
\hline C.glandulosa & Blue & & 0.08 & 0.40 & 0.70 & - & - \\
\cline { 1 - 6 } N.lotus & Red dark & & 0.10 & 0.47 & 0.56 & 0.87 & - \\
\hline
\end{tabular}

Table-6: TLC separation of plant extracts for saponins representing florescence, color and Rf values by using a solvent system chloroform: glacial acetic acids: methanol: water (64: 32: 12: 8 and spray reagent: Vanillin -Sulphuric acid

\begin{tabular}{|c|c|c|c|}
\hline Plants & Color .UV 365 nm & Color with reagent & R.f \\
\hline A.bracteulata & Blue dark & \multirow{5}{*}{ Color less } & No. Spots \\
\hline B.papyrifera & Blue & & \\
\hline B.senegalensis & Blue dark & & \\
\hline C.glandulosa & Blue & & \\
\hline N.lotus & Blue dark & & \\
\hline
\end{tabular}

Table-7: TLC separation of plant extracts for phenolic compound representing florescence, color and Rf values by using a solvent system: Toluene: ethyl acetate: ferric acid: (50: 40:10). And spray reagents: ferric Chloride in water $(0.5 \%)$

\begin{tabular}{|c|c|c|c|c|c|c|c|}
\hline Plants & Color .UV $365 \mathrm{~nm}$ & Color with reagent & \multicolumn{5}{|c|}{$R_{f}$ value } \\
\hline A.bracteulata & \multirow{5}{*}{ Blue brown } & Color less & - & - & - & - & - \\
\hline B.papyrifera & & Brown & 0.08 & 0.20 & 0.30 & 0.52 & 0.58 \\
\hline B.senegalensis & & & 0.09 & 0.16 & 0.33 & 0.48 & 0.56 \\
\hline C.glandulosa & & & 0.10 & 0.18 & 0.30 & 0.57 & - \\
\hline N.lotus & & & 0.08 & 0.24 & - & - & - \\
\hline
\end{tabular}

\section{Brine Shrimp Lethality Test}

The importance of the cytotoxicity from the fact that it is linked with the discovery of anticancer compounds [43]. From a pharmacological point of view, an honest relationship has been found with the Artemia salina lethality test to detect anti-tumoral compounds in terrestrial plant extracts [44]. The significant correlation between the brine shrimp assay and in vitro growth inhibition of human solid tumor cell lines were demonstrated by the national cancer institute (NCI, USA). It is significant because it shows the worth of this bioassay as a pre- screening tool for antitumor drug research [45]. Not only that there's direct correlation between Artemia salina toxicity and $9 \mathrm{~KB}$ (human nasopharyngeal carcinoma) cytotoxicity ( $\mathrm{p}=$ 0.036 and kappa $=0.56$ ). The Artemia salina test was getting used as a prescreen for a panel of six human solid tumor cell lines at the cell culture laboratory of the Purdue Cancer Center [46]. This is an internationally accepted bioassay for screening of antitumor compounds [47]. In this regard, an easy bioassay was used for screening purposes [48]. Thus brine shrimp larvae (brine shrimp nauplii) has been used target organism to detect bioactive compounds in plant extract and toxicity to the present crustacean features a good correlation with anti-tumor activities in man [33] since the brine shrimp responds similarly to the corresponding mammalian system [49]. According to the method described by Meyer et al. [32], methanol extracts were used to determine its cytotoxicity against brine shrimp larvae (LC50) after 24 hours: The results of this study are classified as: LC50 less than $20 \mu \mathrm{g} / \mathrm{ml}$ was considered as highly toxic, LC50 from 20 to 100 $\mu \mathrm{g} / \mathrm{ml}$ as toxic, LC50 from 100 to $500 \mu \mathrm{g} / \mathrm{ml}$ as moderately toxic and from 500 to $1000 \mu \mathrm{g} / \mathrm{ml}$ was weakly toxic according to Padmaja et al. [22]. However, meyer [32]. Considered the LC50 values > $1000 \mu \mathrm{g} / \mathrm{ml}$ as non - toxic or safe. The brine shrimp lethality test revealed the cytotoxicity effects of plants extracts. The crude extract of plant materials were showed considerable results (Table 8 ). The highly effect against brine shrimp larvae was shown by $B$. senegalensis extract $(1.97 \mu \mathrm{g} / \mathrm{ml})$. Also B.papyrifera extract exhibited high result equal to $(14.96 \mu \mathrm{g} / \mathrm{ml})$. On the other hand N.lotus and C.glandulosa revealed moderate values equal to $316.228 \mu \mathrm{g} / \mathrm{ml}$ and 635.130 $\mu \mathrm{g} / \mathrm{ml}$ respectively. However, the A. bracteulata detected nontoxic or safe result, however this is disagree with which was reported by Thirumal et al. [17] who assess the potential antitumor activity of A. bracteolate, several root's extracts were tested against cutaneous melanoma cell line. The petroleum ether extracts notably reduced cell survival. Aristolochic acids are known to be toxic and a rodent carcinogen, in addition to their carcinogenicity, aristolochic acids are also highly nephrotoxic agents [51]. Although the Artemia salina lethality assay is quite inadequate regarding the elucidation of the mechanism of action, 
it's very useful to assess the bioactivity of the plant extracts. The first time that the aerial parts of Cleome, family Capparaceae, extracts and the purified compounds exhibited significant cytotoxic activity (LC50 values $<100 \mu \mathrm{g} / \mathrm{ml}$ ) using brine shrimp lethality assay and are considered as a source of natural agents that would be used as anti-proliferative, antitumor and will provide results in interesting pharmaceuticals of plant origin [52]. This a clear indication of first time achievement of results which were not preceded by any other ones reported in the available literature.

Table-8: Brine shrimp bioassay results of plant extracts

\begin{tabular}{|l|l|l|}
\hline Plants & Part use & $\mathbf{L C}_{\mathbf{5 0}} \boldsymbol{\mu g} / \mathbf{~ m L}$ \\
\hline A. bracteolate & Leaves & $>1000$ \\
\hline B. paprifera & Leaves & 14.963 \\
\hline B. Senegalensis & Leaves & 1.975 \\
\hline C. glandulosa & Leaves & 635.130 \\
\hline N. lotus & Whole plant & 316.228 \\
\hline
\end{tabular}

Keys: $\mathrm{LC}_{50}>20 \mu \mathrm{g} / \mathrm{ml}=$ highly toxic, $20-100 \mu \mathrm{g} / \mathrm{ml}$ as toxic, $100-500 \mu \mathrm{g} / \mathrm{ml}$ moderately toxic, $>1000 \mu \mathrm{g} / \mathrm{ml}$ weakly toxic.

\section{REFERENCES}

1. Girach RD, Khan H, Ahmad M. Botanical identification of Thuhar seldom used as Unani medicine. Hamdard Medicus (Pakistan). 2003.

2. Djeridane A, Yousfi M, Nadjemi B, Boutassouna D, Stocker P, Vidal N. Antioxidant activity of some Algerian medicinal plants extracts containing phenolic compounds. Food chemistry. 2006 Aug 1;97(4):654-60.

3. Elujoba AA, Odeleye OM, Ogunyemi CM. Traditional medicine development for medical and dental primary health care delivery system in Africa. African Journal of Traditional, Complementary and Alternative Medicines. 2005;2(1):46-61.

4. Elghazali GEB. Medicinal Plants in Sudan, Research Institute, Khartoum.2003.

5. Elkhalifa MY. Women income generating activities and the conservation of rural resources: Medicinal, Culinary and aromatic plants in the Sudan. Document of the FAO Regional Office of the Near East. Sustainable Development Department (SD), Food and Agriculture Organization of the United Nations (FAO).2003.

6. Gehlot D and Bohar A. Toxic effect of various plant extracts on the causal organism of typhoid fever. In: Current Science. 2000; (78): 7.

7. Khamis MA, Uhlig HS, Phoris H. Management of Boswellia papyrifera stands for resin production in Jebel Marra area, west Sudan: present situation and future prospects.

8. Ni X, Suhail MM, Yang Q, Cao A, Fung KM, Postier RG, Woolley C, Young G, Zhang J, Lin HK. Frankincense essential oil prepared from hydrodistillation of Boswellia sacra gum resins induces human pancreatic cancer cell death in cultures and in a xenograft murine model. BMC Complementary and Alternative Medicine. 2012 Dec 1;12(1):253.

9. de Almeida PA, da Silva TM, Echevarria A. Mesoionic 5-alkyl-1, 3-dithiolium-4-thiolates: Synthesis and brine shrimp toxicity. Heterocyclic Communications. 2002;8(6):593-600.
10. Efferth T, Greten HJ. Anti-inflammatory and anticancer activity of boswellic acids from frankincense (Boswellia serrata Roxb. et Colebr, B. carterii Birdw.). InForum on Immunopathological Diseases and Therapeutics 2011 (Vol. 2, No. 4). Begel House Inc..

11. Park B, Sung B, Yadav VR, Cho SG, Liu M, Aggarwal BB. Acetyl- 11- keto- $\beta$ - boswellic acid suppresses invasion of pancreatic cancer cells through the downregulation of CXCR4 chemokine receptor expression. International journal of cancer. 2011 Jul 1;129(1):23-33.

12. Suhail MM, Wu W, Cao A, Mondalek FG, Fung KM, Shih PT, Fang YT, Woolley C, Young G, Lin HK. Boswellia sacra essential oil induces tumor cell-specific apoptosis and suppresses tumor aggressiveness in cultured human breast cancer cells. BMC complementary and alternative medicine. 2011 Dec 1;11(1):129.

13. El Ghazali GB, El Tohami MS, El Egami AB, Abdalla WS, Mohammed MG. Medicinal plants of the Sudan. Part IV. Medicinal plants of northern Kordofan. Khartoum: Medicinal and Aromatic Plants Research Institute. 1997:77.

14. Bidchol AM, Wilfred A, Abhijna P, Harish R. Free radical scavenging activity of aqueous and ethanolic extract of Brassica oleracea L. var. italica. Food and bioprocess technology. 2011 Oct 1;4(7):1137-43.

15. Periyasamy A, Mahalingam K. Phytochemical screening and antimicrobial activity from five Indian medicinal plants against human pathogens. Middle East Journal of Scientific Research. 2010;5(6):477-82.

16. Thippeswamy BS, Mishra B, Veerapur VP, Gupta G. Anxiolytic activity of Nymphaea alba Linn. in mice as experimental models of anxiety. Indian journal of pharmacology. 2011 Feb;43(1):50.

17. Thirumal M, Vadivelan R, Kishore G, Brahmaji VS. Aristolochia bracteolata: an overview on pharmacognostical, phytochemical and pharmacological properties. Critical review in pharmaceutical sciences. 2012;1(1):70-82. 
18. Hilu KW, Borsch T, Müller K, Soltis DE, Soltis PS, Savolainen V, Chase MW, Powell MP, Alice LA, Evans R, Sauquet H. Angiosperm phylogeny based on< 011> matK sequence information. American journal of botany. 2003 Dec;90(12):1758-76.

19. El-Ghazali GE, El-Tohami MS, El-Egami AA. Medicinal plants of the Sudan: medicinal plants of the White Nile provinces. National Centre for Research, Medicinal \& Aromatic Plants Research Institute; 1994.

20. Abubakar MS, Musa AM, Ahmed A, Hussaini IM. The perception and practice of traditional medicine in the treatment of cancers and inflammations by the Hausa and Fulani tribes of Northern Nigeria. Journal of Ethnopharmacology. 2007 May 22;111(3):625-9.

21. Abdelgadir AA, Ahmed EM, Eltohami MS. Isolation, characterization and quantity determination of aristolochic acids, toxic compounds in Aristolochia bracteolata L. Environmental health insights. 2011 Jan;5:EHIS6292.

22. NRC: National Research Concil. Aizen-Mukheit Lost crop of Africa Fruit.part National Academies Press.Washington DC. 2008; III. 220_230.

23. Padmaja R, Arun PC, Prashanth D, Deepak M, Amit A, Anjana M. Brine shrimp lethality bioassay of selected Indian medicinal plants. Fitoterapia. 2002 Oct 1;73(6):508-10.

24. Neuwinger HD. African traditional medicine: a dictionary of plant use and applications. With supplement: search system for diseases. Medpharm; 2000.

25. Orwa C, Mutua A, Kindt R, Jamnadass R, Anthony S. Agroforestree Database: a tree reference and selection guide version 4.0. World Agroforestry Centre, Kenya. 2009 Jul;15.

26. Sakine MN, Mahmout Y, Dijoux-Franca MG, Gbenou J, Moudachirou M. In vitro antihyperglycaemic effect of glucocapparin isolated from the seeds of Boscia senegalensis (Pers.) Lam. ex Poiret. African journal of biotechnology. 2012;11(23):6345-9.

27. Vougat RR, Foyet HS, Ziebe R, Garabed RB. Antioxidant activity and phytochemical constituent of two plants used to manage foot and mouth disease in the Far North Region of Cameroon. Journal of intercultural ethnopharmacology. 2015 Jan;4(1):40.

28. Al-Fatimi M, Wurster M, Schröder G, Lindequist U. Antioxidant, antimicrobial and cytotoxic activities of selected medicinal plants from Yemen. Journal of ethnopharmacology. 2007 May 22;111(3):657-66.

29. Mohtasheem U1 Hasan M. Salman A. Munnawar S. Iqbal A. Analgesic and Anti - emetic activity of Cleome viscosa L. Pak J Bot .1. 2011; 43(1): 1192.

30. Pisutthanan S, Plianbangchang P, Pisutthanan N,
Ruanruay S, Muanrit O. Brine shrimp lethality activity of Thai medicinal plants in the family Meliaceae. Naresuan University Journal: Science and Technology (NUJST). 2013 Aug 1;12(2):13-8.

31. Harborne AJ. Phytochemical methods a guide to modern techniques of plant analysis. springer science \& business media; 1998 Apr 30.

32. Harborne JB. Phytochemical methods London Chapman and Hall. 1973.

33. Meyer BN, Ferrigni NR, Putnam JE, Jacobsen LB, Nichols DJ, McLaughlin JL. Brine shrimp: a convenient general bioassay for active plant constituents. Planta medica. 1982 May;45(05):314.

34. McLaughlinJM. Crown gall tumours on potato discs and brine shrimp lethality: two simple bioassays for higher plant screening and fractionation. In $\mathrm{K}$ Hostettmann, Assays for Bioactivity, Academic Press, San Diego.1991; 232.

35. Emad M A. Antibacterial activity and toxicological studies on the oleo-gum resins of Commiphora molmol and Boswellia papyrifera. 2009; 95.

36. Forster Y, Ghaffar A, Bienz S. A new view on the codonocarpine type alkaloids of Capparis decidua. Phytochemistry. 2016 Aug 1;128:50-9.

37. Kashiwada Y, Aoshima A, Ikeshiro Y, Chen YP, Furukawa H, Itoigawa M, Fujioka T, Mihashi K, Cosentino LM, Morris-Natschke SL, Lee KH. Anti-HIV benzylisoquinoline alkaloids and flavonoids from the leaves of Nelumbo nucifera, and structure-activity correlations with related alkaloids. Bioorganic \& medicinal chemistry. 2005 Jan 17;13(2):443-8.

38. Luo C, Shen Z, Li X, Baker AJ. Enhanced phytoextraction of $\mathrm{Pb}$ and other metals from artificially contaminated soils through the combined application of EDTA and EDDS. Chemosphere. 2006 Jun 1;63(10):1773-84.

39. Sakine MA, Mahmout Y, Gbenou J, Agbodjogbe W, Moudachirou M. Effet antihyperglycémiant des extraits de Boscia senegalensis (Pers.) Lam. ex Poiret et de Colocynthis vulgaris (L.) Schrad. Phytothérapie. 2011 Oct 1;9(5):268-73.

40. Newman DJ, Cragg GM, Snader KM. The influence of natural products upon drug discovery. Natural product reports. 2000;17(3):215-34.

41. Jayanthi P, Lalitha P, Shubashini KS. Phytochemical investigation of the extracts of Eichhornia crassipes and its solvent fractionates. Journal of Pharmacy Research. 2011 May;4(5):1405-6.

42. Carocho M, CFR Ferreira I. The role of phenolic compounds in the fight against cancer-a review. Anti-Cancer Agents in Medicinal Chemistry (Formerly Current Medicinal Chemistry-AntiCancer Agents). 2013 Oct 1;13(8):1236-58.

43. Cock IE. The phytochemistry and chemotherapeutic potential of Tasmannia lanceolata (Tasmanian pepper): A review. 
Pharmacognosy Communications. 2013 Oct 1;3(4):13-25.

44. Moshi MJ, Cosam JC, Mbwambo ZH, Kapingu M, Nkunya MH. Testing beyond ethnomedical claims: brine shrimp lethality of some Tanzanian plants. Pharmaceutical Biology. 2004 Jan 1;42(7):547-51.

45. Mackeen MM, Ali AM, Lajis NH, Kawazu K, Hassan Z, Amran M, Habsah M, Mooi LY, Mohamed SM. Antimicrobial, antioxidant, antitumour-promoting and cytotoxic activities of different plant part extracts of Garcinia atroviridis Griff. ex T. Anders. Journal of Ethnopharmacology. 2000 Oct 1;72(3):395-402.

46. Anderson JE, Goetz CM, McLaughlin JL, Suffness M. A blind comparison of simple bench- top bioassays and human tumour cell cytotoxicities as antitumor prescreens. Phytochemical analysis. $1991 \mathrm{Jul} ; 2(3): 107-11$.

47. Mclaughlin JL, Rogers LL, Anderson JE. The use of biological assays to evaluate botanicals. Drug information journal. 1998 Apr;32(2):513-24.
48. Meyer BN, Ferrigni NR, Putnam JE, Jacobsen LB, Nichols DJ, McLaughlin JL. Brine shrimp: a convenient general bioassay for active plant constituents. Planta medica. 1982 May;45(05):314.

49. Hostettmann K. Assays for Bioactivity. Methods in Plant Biochemistry Academic Press, San Diego. 1991; 360 .

50. Solis PN, Wright CW, Anderson MM, Gupta MP and Phillipson JD. "Microcell cytotoxicity assay using Artemiasalina" Planta Medica. 1993; 59, 250-252

51. JOU JH, LI CY, Schelonka EP, LIN CH, Wu TS. Analysis of the analogues of aristolochic acid and aristolactam in the plant of Aristolochia genus by HPLC. Journal of Food and Drug Analysis. 2004;12(1).

52. Afifi MS. Phytochemical and Biological Investigation of Celome brachycarpa Vahl. J PSPR. 2014; 5(9): 3726-3732. 